\title{
IMPULSE PURCHASE BEHAVIOUR: A REVIEW
}

\author{
Amit Mishra* \\ *School Of Management Studies \\ Motilal Nehru National Institute of Technology, \\ Allahabad, U.P. 211002 \\ amitmmails@gmail.com
}

\begin{abstract}
For more than fifty years, researchers have strived hard to form a better understanding of impulse buying (Stern; 1962; Rook et.al; 1987; Rook and Fisher; 1995; Peck and Childers; 2006 ; Chang et.al; 2011). The purpose of this paper is to provide a detailed account of impulse buying behavior. The content analysis of various research work led to the classification of literature into various factors affecting impulse purchase decisions, classifying products into impulse and non impulse items, behavior dimensions of impulse buying and Rook and Fisher (1995, p.305) proposed that consumers tend to control their innate impulsive tendencies as they perceive impulse buying as normatively wrong. This paper will be useful for practitioners and researchers towards understanding of impulsive behavior of consumers and will provide a better insight in
\end{abstract}

Keywords: impulse buying, impulse and non impulse items, purchase decisions, behavioral decisions, perceive.

\section{Council for Innovative Research}

Peer Review Research Publishing System

Journal: International Journal Of Management \& Information Technology

Vol. 10, No 7

editorsijmit@gmail.com

www.jimit.com 


\section{Introduction}

The increasing amount of spending in today's society has created a new life style that has been integrated and accepted among consumers. Owning of items has become an expression of self identity for a lots of consumers which has increased shopping as a lifestyles (Dittamar et.al 1996) and India is rated fifth among the developing countries based upon global retail development index of 30 developing countries drawn up by AT Kearney (2012) reports and retailing in India is expected to grow because of changing life styles and impulse buying becomes critically important for retailers. In this paper we have proposed a comprehensive outline of impulse buying behavior that can be explored and on the basis of which further research can be carried out in future.

\section{Literature Review}

Retailers have realized the power of impulse buying, which is a central points in many purchasing activities and this topic have received considerable research interest in marketing literature(Beatty and Ferrell, 1998;Rook and Fisher,1995;Jones et al.,2003).

\subsection{Definitions of Impulse Buying}

Stern (1962) classified buying behavior as planned and unplanned. As per this classification, planned buying behavior involves a time consuming information search followed by rational decision making (Piron,1991;Stern,1962). Unplanned buying refers to purchases made without advanced planning which involves speedy decision making.

Rook (1987) has quoted kollat and Willet(1969) "impulse purchase is difficult to measure accurately because consumers may be unable or unwilling to articulate their pre purchase intentions".

Rook (1987) has further quoted that "buying impulses are often forceful and urgent, that there isn't much time to think about them. It is a fast experience and It is more spontaneous than cautious...it tend to disrupt the consumer behavior stream."

Piron (1991) uses a conceptualized meaning of unplanned purchasing from et al (1982) saying that "unplanned purchase is a buying action undertaken without a problem having been previously recognized or buying intentions formed prior to entering the store".

\begin{tabular}{|c|c|}
\hline IMPULSE BUYING DEFINITION'S & AUTHORS \\
\hline $\begin{array}{l}\text { Impulse purchase can be defined as any purchase made } \\
\text { without advanced planning. }\end{array}$ & $\begin{array}{l}\text { Clover(1950), Kollat and Willet(1967), Bellenger et } \\
\text { al.(1978) }\end{array}$ \\
\hline $\begin{array}{l}\text { Far More Rapid than unplanned buying and based upon } \\
\text { behavioral response. }\end{array}$ & D' Antoni et al.(1973) \\
\hline $\begin{array}{l}\text { Impulse buying is characterized by high emotional } \\
\text { activation, low cognitive control and largely reactive } \\
\text { behaviour }\end{array}$ & Weinberg et al.(1982) \\
\hline $\begin{array}{l}\text { Impulse purchase is one in which one makes decision to } \\
\text { buy the items while one in store. }\end{array}$ & Cobb and Hover(1986) \\
\hline $\begin{array}{l}\text { Impulsiveness is defined as a tendency to respond } \\
\text { quickly to a given stimulus without deliberation and } \\
\text { evaluation of consequences. }\end{array}$ & Gerbing et al.(1987) \\
\hline $\begin{array}{l}\text { Impulse purchase is powerful and persistent urge to buy } \\
\text { something immediately. }\end{array}$ & Rook(1987) \\
\hline $\begin{array}{l}\text { Impulse purchase is related to store environment and } \\
\text { time pressure }\end{array}$ & lyer(1989) \\
\hline $\begin{array}{l}\text { Impulse purchase is unplanned buying and hedonically } \\
\text { complexed experience }\end{array}$ & Piron(1991) \\
\hline $\begin{array}{l}\text { An impulse purchase is characterized by relatively rapid } \\
\text { decision making and subjective bias in favours of } \\
\text { immediate possession. }\end{array}$ & Rook and Gardner(1993) \\
\hline $\begin{array}{l}\text { An unplanned and sudden buying act, in response to } \\
\text { subjective or external stimuli, accompanied by a powerful } \\
\text { and persistent urge after the purchase followed by } \\
\text { customers emotional, cognitive and behavioral reactions. }\end{array}$ & Xiao and Nicholson(2012) \\
\hline
\end{tabular}

\section{Sources: Compiled by Author}


Contribution Made By Different Author's






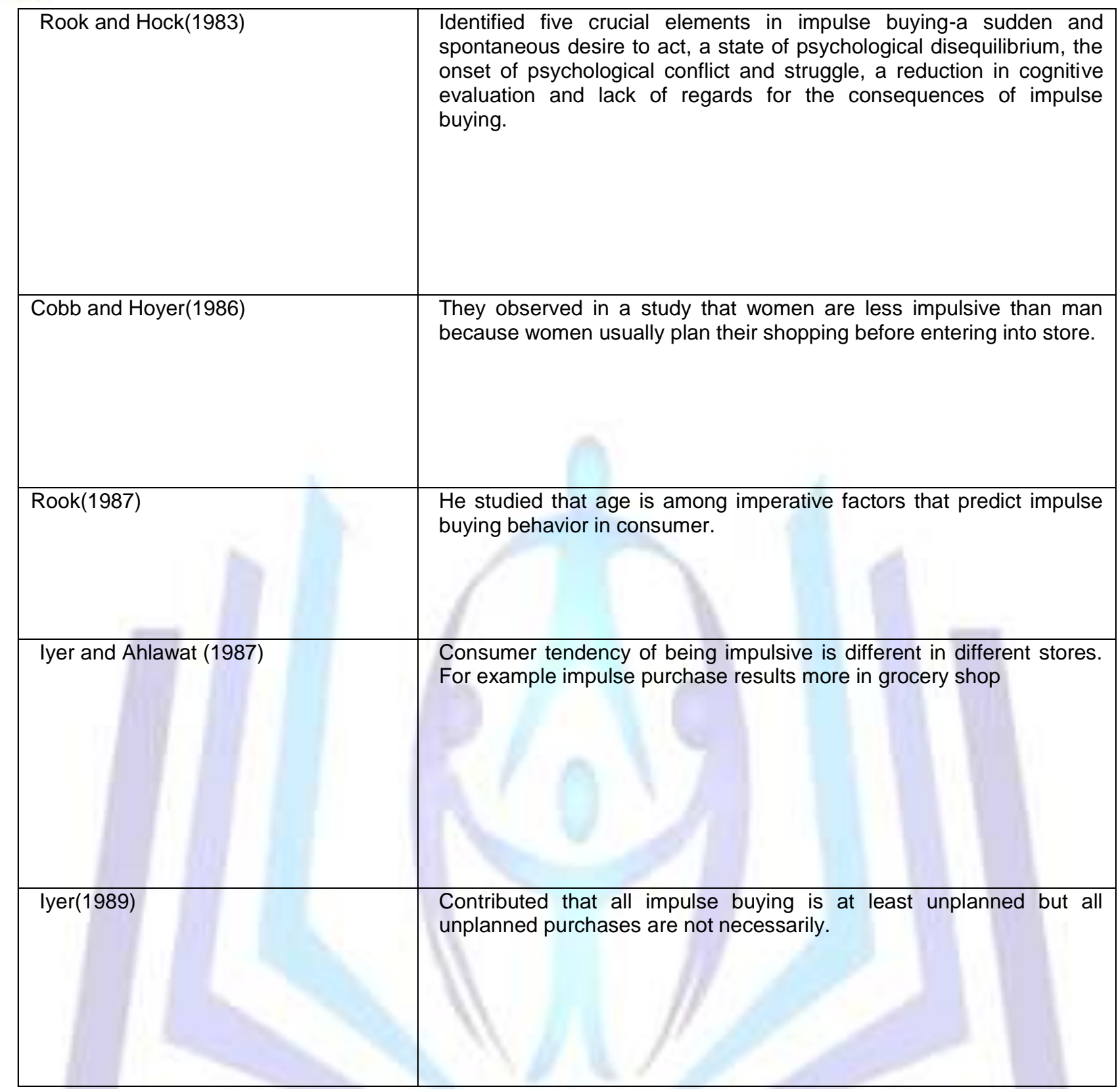

\begin{tabular}{|l|l|}
\hline Abratt and Goodey(1990) & $\begin{array}{l}\text { Contributed those High income shoppers more likely to show higher } \\
\text { impulsive behavior. }\end{array}$ \\
\hline Piron(1991) & $\begin{array}{l}\text { He contributed that impulse buying is a purchase that is unplanned and it } \\
\text { results as an exposure to a stimulus and decided on the spot. }\end{array}$ \\
\hline
\end{tabular}




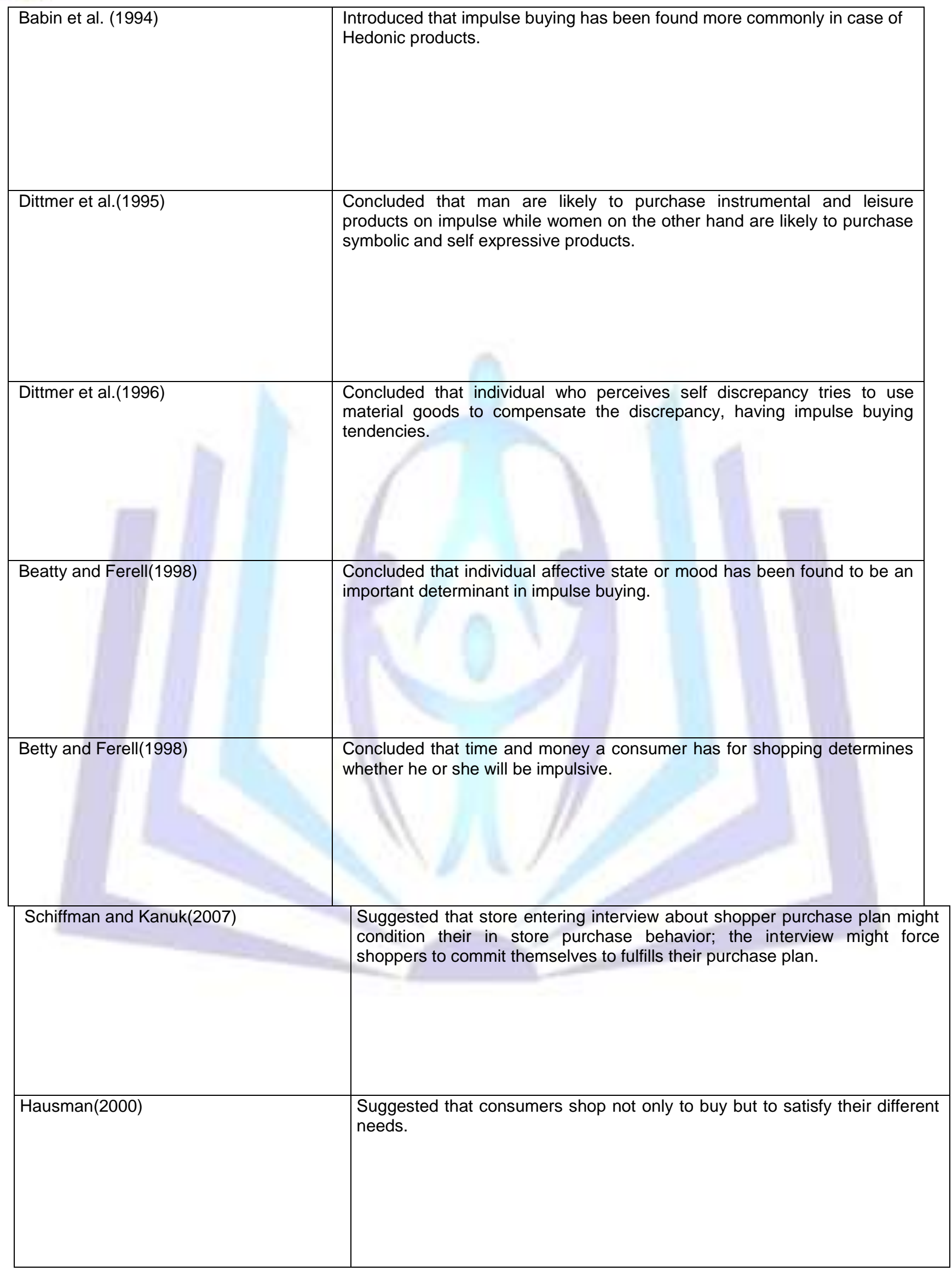




\begin{tabular}{|c|c|}
\hline Youn and Faber(2000) & $\begin{array}{l}\text { Suggested that both positive and negative of consumers are potential } \\
\text { motivators for impulse purchasing. }\end{array}$ \\
\hline Kacen and Lee(2002) & $\begin{array}{l}\text { Studied the impact of cultural forces on impulse purchase. People engage in } \\
\text { impulse purchase who used to have independent self concept. }\end{array}$ \\
\hline Crawford and Malewar(2003) & $\begin{array}{l}\text { Suggested that marketers should promote a good store layout to maximize } \\
\text { the convenience of consumers. }\end{array}$ \\
\hline Zhou and Wong(2003) & Suggested that retail store environment could affect the impulse buying. \\
\hline Luo(2005) & Suggested that product price is an important determinant of impulse buying \\
\hline
\end{tabular}

\begin{tabular}{|l|l|}
\hline Parboteeah (2005) & $\begin{array}{l}\text { Suggested that individual charactorstics like individual age, gender, culture, } \\
\text { mood, materialism, shopping enjoyment and perceived degree of self } \\
\text { discrepancies enhances consumers tendency to show impulsive tendency. }\end{array}$ \\
\hline Park et al.(2006) & Studied fashion and hedonic aspects of impulse purchase. \\
& \\
& $\begin{array}{l}\text { Suggested that point of purchase, signs, displays, packaging encourages } \\
\text { product touch which may increase impulse purchase. }\end{array}$ \\
\hline Peck and Childer (2006) & \\
& \\
\hline
\end{tabular}




\begin{tabular}{|c|c|}
\hline Kathleen and Ronald(2007) & $\begin{array}{l}\text { Explained that impulse buying is resulted from the depletion of common but } \\
\text { limited resources that govern by self control. }\end{array}$ \\
\hline Kaur and Singh(2007) & Studied the impacts of impulse purchasing tendency of Indian youth \\
\hline Dhar(2007) & Studied that Packaging plays an important role at impulse purchase. \\
\hline Mattila and Wirtz(2008) & $\begin{array}{l}\text { Found that store environment factors such as social factors have a positive } \\
\text { impact on impulse buying behavior. }\end{array}$ \\
\hline Dawson and Kim(2009) & $\begin{array}{l}\text { Studied affective cognitive aspects and found a significant relationship between } \\
\text { a person affective and cognitive state. }\end{array}$ \\
\hline Harmancioglu et al.(2009) & $\begin{array}{l}\text { Suggested that in case of new product, product knowledge, consumer } \\
\text { excitement and consumer esteem drives impulse buying behavior. }\end{array}$ \\
\hline Sharma et al.(2010) & Studied the variety seeking behavior of impulse buying. \\
\hline Dong-jenn yang et al.(2011) & $\begin{array}{l}\text { Studied affective cognitive aspects and found a significant relationship between } \\
\text { a person affective and cognitive state. }\end{array}$ \\
\hline Minal et al.(2012) & Found that display is a very important driver of impulse behavior. \\
\hline
\end{tabular}

Sources: Compiled by Author 


\section{Factor Influencing Impulse Purchase}

A consumer impulse purchase tendency is being affected by internal as well as external factors (Wansink, 1994).Increased exposure to certain external stimuli increases the impulse buying tendency (lyer, 1989).

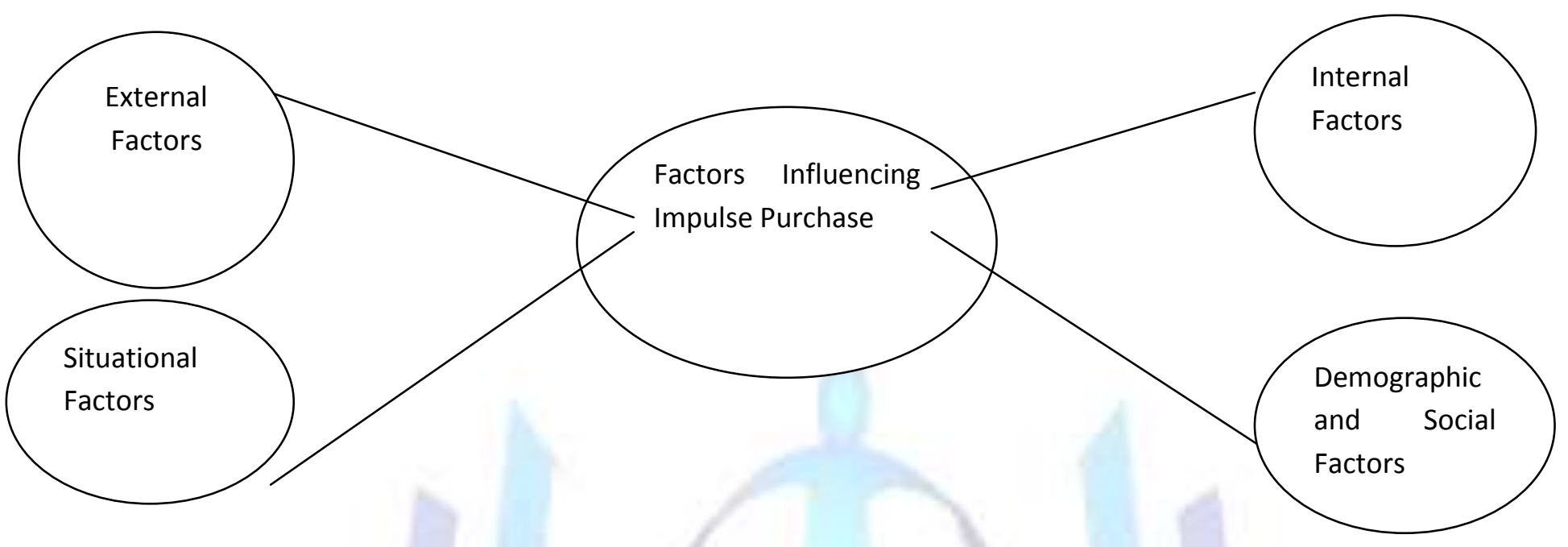

\section{External Factors of Impulse Buying:}

Refers to all those factors that are placed and controlled by the marketers in attempt to lure consumers into purchase behavior (Youn and Faber, 2000).Consumers experiences an urge to impulsively purchase when visually encountering cues such as promotional activities (Dholakia, 2000; Rook 1987).

External marketing cues not only attract new customers but also promotes up selling and cross selling

(Dawson and Kim, 2009).In store employees are promotional techniques employed to increase impulse buying of products. Some examples of this techniques in-store setting, on-self positions, price-off promotions, sampling, coupons and in store displays.

Exclusive availability of certain products, clean ambience and spacious formats are some of the factors that enhance the impulse purchase tendency. Ease in the mode of payments like credit cards and incentives for doing extra shopping can also increase an impulse purchase.

\section{Internal Factors of Impulse Buying}

It depends entirely upon the individuals. Internal factors constitute internal cues and characteristics of individual that make them involve in impulse buying behavior. Such factors involve consumer's personality traits which determine the degree of impulse buying tendency, internal cues such as emotional states.

Researchers have provided theoretical framework for examining impulse buying related to psychological variables, hedonic variables and situational variables in a shopping context. Internal stimuli are being processed by consumers and when a consumer feels an irresistible urge to buy, he/she feels compelled for impulse purchase. Several researchers have suggested that consumer's personality traits help in determining the degree of impulse buying tendency.

\section{Situational Factors of Impulse Buying}

Situational Factors refers to those external factors which come from the shopping environment when buyers come into contact with certain kind of visual stimuli.

According to Belk(1974), situation comprises of all the factors "particular to a time and place of observation which do not follow from a knowledge of personal and stimulus attributes, which have a systematic and demonstrable effect on current behavior" . Thus it involves elements like Physical Surrounding, Social Surrounding, Time and Shopping Task.

\section{Demographic and Social Factors}

From the literature review, it is clearly understood that majority of the individuals are females who are involved in impulse purchase and large part of consumer base are literate with higher disposable income.

Social Factors also influences impulse buying and it involves store employees and other customer's. Store employees friendliness has a direct impact on the impulse purchase intentions of the customer and friends accompanying the customers also increase the chances of impulse purchase.

\section{Scope of Future Research}

Further research can be carried out how promotional tools affect old and young people. 


\section{ISSN 2278-5612}

Further study can be done on the impact of the impulse purchase tendency of young women.

Future research could be extended to study the impact of promotional tools like cross selling and up selling.

Reference:

1. AT Kearney. (2012). Global Retail Expansion: Keeps on Moving, Retrieved From http://www.atkearney.com/documents/10192/4799f4e6-b20b-4605-9aa8-3ef451098f8a.

2. D'Antoni, J. S. and Shenson, H. I. (1973). 'Impulse buying revisited: A behavioural typology'. Journal of Retailing, 49(1), 63-76.

3. Engel, James F. and Roger D. Blackwell (1982), "Consumer Behavior," Hinsdale, IL: Dryden Press.

4. Rook DW, Hock SJ. Consuming impulses. In: Holbrook MB, Hirschman EC, editors. Advances in Consumer Research, vol. 12. Provo (UT): Association for Consumer Research; 1985. p. 23-7.

5. Iyer Easwar S. and Sucheta S. Ahlawat (1987), "Deviations from a Shopping Plan: When and Why Do Consumers Not Buy as Planned," in Advances in Consumer Research, Vol. 14, eds. Melanie Wallendorf and Paul Anderson, Provo, UT.: Association for Consumer Research, 246249.

6. Crawford and Malewar. (2003). The Influence of Culture on Consumer Impulsive Buying Behavior. Journal of Consumer Psychology, 12(2), 163-176.

7. Luo, X. (2005): How Does Shopping With Others Influence Impulsive Purchasing. Journal of Consumer Psychology, 15(4), pp. 288-294.

8. Sharma, P., Sivakumaran, B., \& Marshall, R. (2010). Impulse buying and variety seeking: A trait-correlates perspective. Journal of Business Research, 63(3), 276-283.

9. Dong-Jenn Yang, Kuang Chuan Huang and Xuanxiaoqing Feng (2011), "A Study of the Factors that Affect the Impulsive Cosmetics Buying of Female Consumers in Kaohsiung" International Journal of Business and Social Science, Vol. 2, No. 24

10. Wansink, Brian (1994a), "Advertising's Impact on Category Substitution," Family and Consumer Sciences Research Jo u rnal, 23 (2), 166-82.

11. Zhou, L., \& Wong, A. (2003). Consumer impulse buying and in-store stimuli in Chinese supermarkets. Journal of International Consumer Marketing, 16, 37-53.

12. Babin, B. J., W. R. Darden, and M. Griffin. "Work and/or fun: Measuring hedonic and utilitarian shopping value," Journal of Consumer Research (20), 1994, pp 644-656.

13. Cobb CJ, Hoyer WD. Planned versus impulse purchase behavior. J Retail 1986;62:67-81 [Winter].

14. Kathleen D. and Ronald J. (2007). Spent Resources: Self-Regulatory Resource Availability Affects Impulse Buying. JOURNAL OF CONSUMER RESEARCH, Inc.33:537-547.

15. Harmancioglu, N.; Finney, R. Z.; Joseph, M. (2009). Impulse purchases of the new products: an empirical analysis. Journal of Product and Brand Management,Vol.18 No.1, 27-37.

16. Belk RW 1974. An Exploratory Assessment of Situational Effect in Buyer. J. Mark. Res., 11: 156- 163.

17. Dawson S. Kim M. (2009). "External and internal trigger cues of impulse buying online", Direct Marketing: An International Journal, 3 (1),20:34.

18. Kaur, P. and Singh, R. (2007). Uncovering retail shopping motives of Indian youth .Young Consumers, 8(2), 128138 .

19. Kacen, J.J. and Lee, J.A. (2002). The Influence of Culture on Consumer Impulsive Buying Behavior. Journal of Consumer Psychology, 12(2), 163-176.

20. Gerbing, David W., Ahadi, Stephan A., \& Paton, Jim H. (1987). Toward a conceptualization of impulsivity: Components across the behavioral and self-report domains. Multivariate Behavioral Research, 22, 357-379.

21. Xiao, S. H. and Nicholson, M. (2012). A Multidisciplinary Cognitive Behavioural Framework of Impulse Buying: A Systematic Review of the Literature. International Journal of Management Reviews 49(1), 63-76.

22. Prasad, V.K. (1975). Unplanned buying in two retailing settings. Journal of Retailing, 51(3), 3-12.

23. Dittmar, H., Beattie, J. and Friese, S. (1996). Objects, Decision Considerations and Self-Image in Men's and Women's Impulse Purchases, Acta Psychologica, 93: 187-206.

24. Beatty, S., Ferrell, E. (1998), "Impulse Buying: Modeling Its Precursors," Journal of Retailing, Vol. 74,No.2, pp.169-191.

25. Rook, D.W. and Fisher, R.J. (1995), "Normative influences on impulsive buying”, Journal of Consumer Research, Vol. 22 No. 3, pp. 305-313

26. Jones, M. A., Reynolds, K.E., Weun, S. and Beatty, S.E. (2003). The product-specific nature of impulse buying tendency. Journal of Business Research, 56 (7), 505-511.

27. Stern, H. (1962), "The Significance of Impulse Buying Today," Journal of Marketing ,Vol.26,No.2,pp.59-62.

28. Piron F (1991). "Defining Impulse Purchasing." Adv. Consum. Res., 18:509-514.

29. Rook, D.W. (1987), "The buying Impulse," Journal of Consumer Research, Vol.14,pp. 189-199.

30. Kollat, D.T., and Willett, R.P. (1967), "Customer Impulse Purchasing Behavior," Journal of Marketing Research, Vol.4, No.1, pp. 21-31.

31. Clover, V. T. (1950), "Relative Importance of Impulse Buying in Retail Stores", Journal of Marketing, Vol. 25, July, pp. 66-70.

32. Bellenger, D.N., Robertson, D.H. and Hirschman, E.C. (1978), " Impulse buying varies by products," Journal of advertising Research, Vol.18,No.6, 15-18

33. Weinberg, P., and Gottwald, W. (1982), "Impulsive Consumer Buying as a Result of emotions," Journal of Business research, Vol.10,No.1,pp. 43-57. 
34. Cobb, C.J. and Hoyer, W.D. (1986), "Planned versus impulse purchase behavior," Journal of retailing, Vol.62, No.4, pp. 384-409.

35. Iyer, E. S., Park, C. W., Smith, D. C. (1989), " The effects of situational factors on in-store grocery shop," Journal of Consumer Research, Vol.15No.4,pp. 422-433.

36. Rook DW, Gardner M.(1993). "In the mood: impulse buying's affective antecedents," ResConsum Behav vol. 6. Greenwich, CT: JAI Press; pp. 1-28.

37. Bellenger, DN, Robertson, DH \& Hirschman, EC 1978, 'Impulse buying varies by product', Journal of Advertising Research, vol. 18, no. 6, pp. 15-18.

38. Tversky, A., \& Kahneman, D. (1974). Judgment under uncertainty: heuristics and biases. Science, 185, $1124 \pm 1131$.

39. Iyer, E. S., Park, C. W., Smith, D. C. (1989), " The effects of situational factors on in-store grocery shop," Journal of Consumer Research, Vol.15No.4,pp. 422-433.

40. Abratt, R. and Goodey, D. S. (1990), "Unplanned Buying and In-store Stimuli in Supermarkets," Managerial and Decision Economics, vol.11No.2, pp.111-122.

41. Schiffmann, L.G. and Kanuk, L.L. (2007). Consumer Behavior. Prentice-Hall of India.

42. Hausman, A. (2000). A Multi-Method Investigation of Consumer Motivations in Impulse Buying Behavior, Journal of Consumer Marketing, 17(5): 403-419.

43. Youn, S. and Faber, R. J. (2000),"Impulse buying: its relation to personality traits and cues", Advances in Consumer Research, Vol. 27, pp. 179-185.

44. Parboteeah, D.V. (2005). A Model of Online Impulse Buying: An Empirical Study, Doctoral Dissertation, Washington State University.

45. Park, E. J., Kim, E.Y., and Forney, J .C. (2006) "A structural model of fashion-oriented impulse buying behavior," Journal of Fashion Marketing and Management, Vol.10, No.4, pp. 433 - 446.

46. Peck,J. and Childers, T.L.(2006), "If I touch it I have to have it: Individual and environmental influences on impulse purchasing", Journal of Business Research ,59,pp. 765-769.

47. Beatty, S.E. \& Ferrell, M.E. (1998). Impulse buying: Modeling its precursors. Journal of Retailing, 74 (2), 169-191.

48. Dhar, Mainak. (2007), "Brand Management," 101. Singapore: John Wiley \& Sons.

49. Mattila, A.S. and Wirtz, F. (2008). The Role of Store Environmental Stimulation \& Social Factors on Impulse Purchasing, Journal of Services Marketing, 22(7): 562-567.

50. Minal, S., Sanjay, G., \& Shrivastava Urvashi, S. (2012), "Effect Of Emerging Trends In Retail Sector On Impulse Buying Behavior-With Reference To Chhattisgarh Region," International Journal of Engineering and Management Sciences, 3(2),pp. 142-1451.

51. Youn, S. and Faber, R. J. (2000),"Impulse buying: its relation to personality traits and cues", Advances in Consumer Research, Vol. 27, pp. 179-185.

52. Dholakia, U.M. (2000). Temptation and Resistance: An Integrated Model of Consumption Impulse Formation and Enactment, Psychology \& Marketing, 17(11): 955-982. 